\title{
浅析大坝防浪墙“现浇+预制+现浇” 施工法
}

李亚斌

中国水电建设集团十五工程局有限公司国际工程公司

DOI:10.32629/hwr.v3i3.2007

[摘 要] 老挝南欧江六级水电站大坝为复合土工膜结构,大坝防浪墙进行施工时,对原现浇施工方案进行二次优化,决定采用 “现浇十预制十现浇” 的混合施工法。该方案通过把握关键性施工工序, 不仅对坝前土工膜起到很好的保护作用, 而且缩短了防 浪墙工期,加快了进度,极大的提高了工程质量,降低了工程成本。本文仅供参考和借鉴。

[关键词] 防浪墙; 预制; 现浇; 关键工序

\section{1 防浪墙施工概况}

老挝南欧江六级水电站复合土工膜面板堆石坝, 由于老 挝一年雨季持续时间长达近 6 个月时间, 为防止雨季汛期库 区波浪翻越坝顶, 造成坝体损坏, 因此在坝顶靠近库区一侧 设有防浪墙, 起到防洪防浪、保护坝体和坝后电站厂房的作 用。老挝南欧江六级水电站大坝防浪墙为 “ $L$ ” 型, 整体长度 为 $362.09 \mathrm{~m}$, 防浪墙高 $4.35 \mathrm{~m}$, 墙体宽度 $0.5 \mathrm{~m}$, 要求在 3 个月 之内施工完毕。

根据设计图纸要求, 防浪墙需现浇施工, 由于防浪墙施 工与坝前土工膜铺设范围较近, 任何防护均不能保证施工期 间对土工膜起到有效保护, 为了减少因防浪墙施工所引起对 土工膜的伤害, 在保证防浪墙功能、防浪墙断面面积、强度、 抗滑稳定及抗倾覆满足设计要求前提下, 经四方商定, 防浪 墙施工采用现浇 (底板)+预制 (墙体) +现浇 (三角部分) 的优 化方案进行施工。

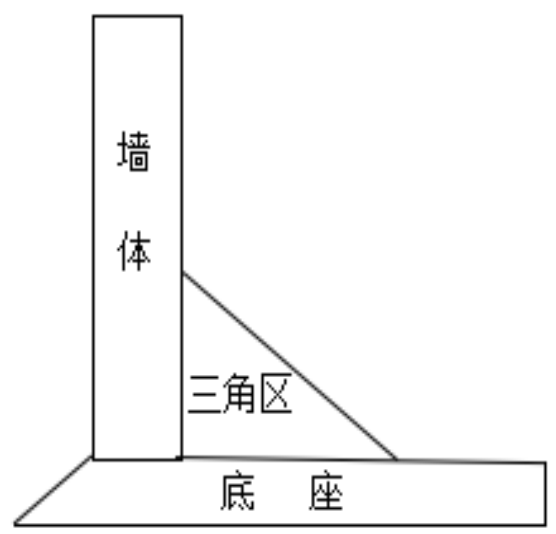

图 1：防浪墙体型简易图

\section{2 采用 “现浇+预制+现浇” 方案的原因}

2.1 防浪墙工期短、施工难度大

老挝南欧江六级水电站大坝防浪墙施工自 2015 年 1 月 开始, 要求 2015 年 3 月底完成, 在主体工程基本完工, 协作队 伍人员减少的情况下, 人力物力无法保证工期。另外, 坝前土 工膜易损坏, 为了确保防浪墙施工期间土工膜安全运行, 传 统防浪墙整体现浇施工无法满足要求, 而现浇 (底板) +预制
(墙体)+现浇 (三角部分) 施工法可以完全避免因浇筑墙体时 对土工膜造成的损坏。

2.2 防浪墙结构设计简单

老挝南欧江六级水电站大坝防浪墙结构简单, 只存在直 线段一种。根据防浪墙结构体型要求, 防浪墙施工分三道工 序, 先同时进行底座现浇施工及预制墙体, 然后吊装预制墙 体与底座拼装成型, 最后进行接茬二期混凝土浇筑施工、养 护与修补。

2.3 防浪墙施工完成后整体美观

防浪墙底座与预制墙体同时施工, 便于施工安排, 节省 工期。现浇底座与预制侧墙部分通过三角区作为固定支架连 接, 确保防浪墙整体性。

\section{3 “现浇+预制+现浇” 施工工艺}

3.1 底座施工流程

基础处理一钢筋制安一模板制安(模板采用内拉式固定) 一混凝土浇筑 $\left(8 \mathrm{~m}^{3}\right.$ 罐车配合简易溜槽直接入仓 $)$ 一拆模养护。

3.2 预制墙体吊装施工流程

预制场转运一现场吊装一预制墙体定位、校正、固定。

3.3 二期混凝土浇筑施工流程

预制墙体吊装、加固完成后进行接茬处二期混凝土浇筑 施工, 首先进行钢筋绑扎施工, 最后进行模板安装施工及混 凝土浇筑施工。

\section{4 关键性工序一预制墙体制作与吊装}

4.1 预制墙体制作与吊装控制要点

如图 2 所示:

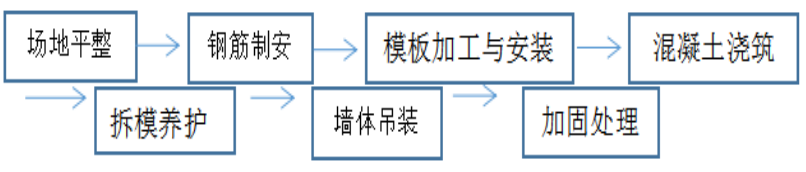

图 2 控制要点图

4.2 场地整平

防浪墙预制墙体在预制场进行预制施工, 对预制场地进 行初整平处理, 预制底座微整平, 然后进行底座混凝土浇筑 施工, 底座尺寸 $4 \mathrm{~m} \times 3 \mathrm{~m}$, 平均浇筑厚度 $10 \mathrm{~cm}$, 预制底座计划 
浇筑 20 个。

4.3 钢筋制安

钢筋制作在钢木加工厂提前进行, 按照设计图纸尺寸下 料、弯曲加工, 并按照仓号、号码分类堆存, 使用时专人负责 发料, 运至预制场进行绑扎施工。钢筋连接采用电焊焊接。 现场安装由专业技术员负责, 根据设计图纸严格测量放线, 精心操作, 保证钢筋规格、尺寸、间距、焊接接头等满足设 计要求。

\section{4 模板加工与安装}

上、下游侧模板采用常规小型钢模板, 模板支撑钢结构 采用两侧对拉。横坚围图采用 $\Phi 48$ 钢管固定, 间排距尺寸为 $100 \times 75 \mathrm{~cm}$ 。

\section{5 混凝土浇筑}

混凝土拌制由拌合站拌制, 采用 $8 \mathrm{~m}^{3}$ 搅拌罐车运输并直 接入仓, 人工配合平仓。 $\Phi 50 \mathrm{~mm} 、 \Phi 30 \mathrm{~mm}$ 插入式振捣器机械 振捣, 专人负责, 振捣间距小于 $30 \mathrm{~cm}$, 深入下层混凝土不小于 $5 \mathrm{~cm}$; 振捣时间以混凝土表面不再明显下沉, 不出现气泡并泛 浆时视为振捣密实。视情况每一处振捣时间控制在 15 20s 左右。收面为人工收面, 并进行二次压光, 平整度满足 $2 \mathrm{~m}$ 靠 尺检查在 $\pm 5 \mathrm{~mm}$ 之内。

\section{6 拆模养护}

混凝土浇筑完成 1 2 天后即可拆模, 拆模后对麻面、错 台等缺陷及时处理, 7 天后转运至临移位。混凝土初凝后及 时开始养护, 土工布覆盖, 混凝土连续养护, 养护期内始终使 混凝土表面保持湿润, 保温、保湿养护不少于 28 天, 混凝土 养护由专人负责, 并应作好养护记录。

4.7 墙体吊装

预制墙体养护 15 天后进行吊装作业, 吊装采用 $50 t$ 汽车 吊车在临时堆存场吊装, $40 \mathrm{t}$ 平板汽车运输至施工, 平板车每 次运输 2 块, $50 \mathrm{t}$ 汽车吊车在大坝坝顶进行吊装作业施工, 人
工配合作业。

\section{8 加固处理}

第一片预制墙体吊装到位后, 及时将墙体预埋钢筋与底 座预埋钢筋进行焊接施工 (焊接 $4 \sim 6$ 根即可), 然后对墙体与 底座接触位置进行加固, 确保墙体垂直度满足设计要求。第二 片吊装到位后, 及时将墙体预埋钢筋与底座预埋钢筋焊接并 于第一片墙体连接, 确保两片整体性, 吊装作业依次施工。

相邻两片墙体吊装、加固完成后, 即可进行二期混凝土 钢筋绑扎及模板安装施工, 墙体及底座钢筋预埋长度均大于 $40 \mathrm{~d}$, 接触处段预埋长度满足设计要求, 该段接茬处钢筋只是 为了固定预制墙体进行个别钢筋搭接焊接, 剩余钢筋搭接不 再进行焊接。相邻二期混凝土浇筑时, 伸缩缝按照设计要求 填充闭孔泡沫板。

\section{5 结束语}

老挝南欧江六级水电站项目大坝防浪墙采用 “现浇+预制 +现浇” 的优化方案进行施工, 缩短了工期, 加快了进度, 极大 的提高了工程质量, 降低了劳动强度。在人员和设备紧缺的情 况下仍然满足了合同工期并确保了防浪墙混凝土的外观质量, 节省了人工、设备及材料等。避免了用大量模板备仓现场浇 筑、人工墙体的打磨、脚手架拆除等繁杂工序, 有效的降低了 工程成本, 得到了业主和监理方的认可, 提升了施工单位的企 业形象, 为以后类似防浪墙施工积累了经验。

\section{[参考文献]}

[1]郑雪英.预制定型钢模在现浇防浪墙施工中的成功 应用[J].施工技术,2015,8(5):23。

[2]王华.苏丹麦洛维大坝右岸面板堆石坝面板及防浪墙 硅施工方案[J].水利电力科技,2007,12(33):4.

[3] 郑毅.深弧型防浪墙在堤防工程中的应用分析[J].建 材与装饰,2018,(42):283-284. 